\title{
Propaganda, Public Information, and Prospecting: Explaining the Irrational Exuberance of Central Place Foragers During a Late Nineteenth Century Colorado Silver Rush
}

\author{
Susan M. Glover
}

Published online: 25 August 2009

(C) The Author(s) 2009. This article is published with open access at Springerlink.com

\begin{abstract}
Traditionally, models of resource extraction assume individuals act as if they form strategies based on complete information. In reality, gathering information about environmental parameters may be costly. An efficient information gathering strategy is to observe the foraging behavior of others, termed public information. However, media can exploit this strategy by appearing to supply accurate information while actually shaping information to manipulate people to behave in ways that benefit the media or their clients. Here, I use Central Place Foraging (CPF) models to investigate how newspaper propaganda shaped ore foraging strategies of late nineteenth-century Colorado silver prospectors. Data show that optimistic values of silver ore published in local newspapers led prospectors to place mines at a much greater distance than was profitable. Models assuming perfect information neglect the possibility of misinformation among investors, and may underestimate the extent and degree of human impacts on areas of resource extraction.
\end{abstract}

Keywords Central place foraging · Social learning · Natural resource extraction · Human behavioral ecology . American frontier

S. M. Glover $(\bowtie)$

University of California, Davis,

Davis, CA, USA

e-mail: smglover@ucdavis.edu

S. M. Glover

Rocky Mountain Biological Laboratory,

Gothic, CO, USA

\section{Introduction}

Throughout the nineteenth century, novelists, poets, and government politicians perpetuated the myth that the American frontier was a place of opportunity, progress, freedom, and ideal living (Billington 1967). This myth was deeply rooted in the psyche of those who migrated West following promises of relatively untapped natural resources (e.g., minerals, timber, furs). Those optimistic immigrants enthusiastically invested their labor, dollars and lives in the hopes of benefiting from the extraction of natural resources on the frontier. There was no guarantee of riches and prestige but Western mining towns used propaganda and outright fraud to attract migrants (Wyman 1979). Frontier towns that experienced a rapid economic boom often soon went bust.

It is not well established how individuals choose their economic strategies under risky and uncertain conditions such as these. The traditional behavioral ecology assumption that individuals have the experience to choose strategies approximating those that would be based on perfect information (Winterhalder and Smith 1992; Smith and Winterhalder 1992; Laland and Brown 2002) makes little sense in Western boomtowns, where environmental quality was so difficult to assess. This paper examines how the method by which individuals acquired information shaped central place foraging strategies of late nineteenthcentury silver prospectors in the Gothic, Colorado area.

\section{Central Place Foraging and Information Gathering Strategies}

Behavioral ecology models are designed to investigate optimal foraging strategies of individuals (e.g., prey type, 
optimal load size, patch choice, time spent in a patch). Central Place Foraging (CPF) models, first described by Orians and Pearson (1979), are distinct in that they assume goods are obtained in one location, and the rate at which those goods are delivered to a home base for consumption, feeding to offspring, or storage is optimized. This means the potential benefit of prey items (e.g., kcal, protein, vitamins) should outweigh costs of pursuit, handling, and transport. CPF models predict that, with increasing distance away from a central home base, foragers will require larger rewards. Larger rewards might be accomplished through field processing to increase transport efficiency (Metcalfe and Barlow 1992; Bettinger and Malhi 1997; Beck et al. 2002), choosing higher quality patches (Orians and Pearson 1979), or choosing higher quality prey (Cannon 2003).

Like most behavioral ecology models, CPF models assume that the forces of natural selection shape behavior so that by whatever mechanism, individuals act as if they choose optimal strategies based on complete information (Winterhalder and Smith 1992; Smith and Winterhalder 1992; Laland and Brown 2002). However, there is a growing trend to focus directly on cognitive mechanisms by which individuals acquire information and how imperfect information shapes strategies (Krebs and Davies 1997). For example, in a formal model Dornhaus et al. (2006) demonstrate how the search for good information as well as resources might alter CPF predictions. Social foragers, such as bees, may choose to sacrifice short-term foraging efficiency by carrying only partial loads of resources back to their home base. This strategy is adaptive if one considers that once back in the hive individuals can exchange valuable information. Costs of carrying a partial load can be compensated by the value of learning locations of high quality ephemeral resource patches.

If individuals must make decisions based on imperfect information with limited time and energy, simple heuristics (or rules-of-thumb) can be a low cost and effective way to assess the environment and choose an optimal strategy (Gigerenzer and Todd 1999). For example, Landa and Wang (2001) demonstrate that Chinese middlemen reduce uncertainty of imperfect rubber contracts by preferring to trade with members of the same clan rather than calculate expected profits from contracts with each potential dealer. Some effective heuristics involve social learning (e.g., success or frequency bias) and can allow individuals to quickly acquire information that would otherwise be prohibitively costly to gather through personal experience. Social learning can often lead to adaptive behaviors, but social cues are sometimes misleading (purposefully or not) which leads to non-adaptive behaviors (Boyd and Richerson 1985; Richerson and Boyd 2005).
One usually reliable type of social cue is public information produced by incidental byproducts of the foraging behaviors of others (Valone and Templeton 2002). By observing others' unsuccessful foraging in a patch, an individual can know to stay or leave instead of wasting time to personally sample it. Because public information is based on incidental cues individuals produce as they forage, it is likely to be unbiased. It is empirically well documented that individuals (mostly bird species) are able to improve estimates about environmental parameters and reduce estimation time by using public information (Valone and Templeton 2002; Danchin et al. 2004; Dall et al. 2005).

However, the use of public information can be a double-edged sword. While social learning frequently leads to optimal strategies, it can also lead to suboptimal behaviors. As suggested by analytical models (Bikhchandani et al. 1992; Morris and Shin 2002), any uncertainty or noise in a public signal can lead to large groups of individuals choosing inefficient strategies. Even a small amount of uncertainty or noise in a public signal can inspire a few individuals to base their economic strategies on inaccurate information. Social learners may observe these individuals, copy them, and pass suboptimal behaviors to other individuals. This "informational cascade" means that one bad signal can get magnified and lead large groups of individuals to adopt strategies based on poor public information. Thus, events of mass hysteria can be explained by the fact individuals rely on public information.

The degree to which the use of public information leads to efficient and well-informed strategies is not yet resolved (Laland 1996; Giraldeau et al. 2002). However, when the costs of personally surveying the environment are large, it might be worth the risks of informational cascades to use public information. It is likely that in environments where it is difficult for individuals to personally survey their environment there would be strong selective pressures for cognitive mechanisms that rely on the use of social cues, especially public information.

In humans, media (newspaper, television, Internet) can exploit the cognitive mechanisms associated with social learning. While not well understood, media appears to play an important role in "herding," where investors appear to choose investment strategies as a group without planned behavior (Shiller 2000). Surprisingly, this behavior is not necessarily related to economic changes such as the arrival of new information or variation in pricing (Cont and Bouchaud 2000). The key to understanding this behavior may be that humans are like African buffalo (Prins 1996) or Hamadryas baboons (Smuts et al. 1987), where the appearance of group level decisions is actually an aggregation of individual strate- 
gies involving social learning. Individuals may appear to be "irrationally exuberant" investors as a group, but are simply individually selecting strategies based on available information. Media provide what appears to be reliable information from unbiased and detached observers, but in reality provide information biased by incentives such as enhancing subscriptions (Shiller 2000). Cognitive mechanisms respond to social cues presented in newspapers, but biased information leads large groups of individuals to adopt a particular economic strategy regardless of optimality. Thus, individuals appear to have "herd" behavior, but are in fact making individual decisions. The herding phenomenon is well-documented by theoretically and empirically oriented economists (Cont and Bouchaud 2000), but the potential impact of herding on the market as well as the specific role of the media for inspiring herding among large groups of investors is still not well understood (Wermer 1999; Cont and Bouchaud 2000; Morris and Shin 2002; Shiller 2000).

\section{Colorado Case Study}

In late May of 1879 the Jennings brothers discovered wire silver at the Sylvanite lode in the high Elk Mountains of Gunnison County, Colorado (Strahorn 1881; Haase 1971; Vandenbusche 1980; Fig. 1). Despite the rough alpine landscape and violent summer storms, prospectors flocked to the newly settled areas. Most set up tents on the confluence of the East River and Copper Creek (Vandenbusche 1980), where the town of Gothic was soon incorporated (July 17th, 1879; Gunnison County Records 1879). Gothic quickly became the main supply and shipping center for the many prospectors and miners who swarmed the slopes. Enthusiasm for Gothic even left the nearby towns of Hillerton and Virginia City almost deserted (Wolle 1949; Haase 1971).

By 1880, 1,225 people resided in Gothic, mostly of northern European ancestry (97\% "white"), male (92\%), and without families $(30 \%$ of men were married, but only $18 \%$ of those brought their wives to Gothic: United States Bureau of the Census 1880). Gothic's economy focused on mining and prospecting for silver ore. The majority of male residents $(67 \%)$ declared their occupation to be miner or prospector (United States Bureau of the Census 1880). No women declared their occupation to be miner or prospector,

\footnotetext{
${ }^{1}$ The term "irrational exuberance" was first used by Alan Greenspan in 1996 during a speech about the escalation of stock value regardless of actual worth (Shiller 2000). This term was particularly memorable as it predicted the subsequent crash in stock prices. Shiller's (2000) book Irrational Exuberance expanded the term to apply to speculative bubbles in the housing market and dot.com companies, and discusses the role of the media in shaping individual investment behaviors.
}

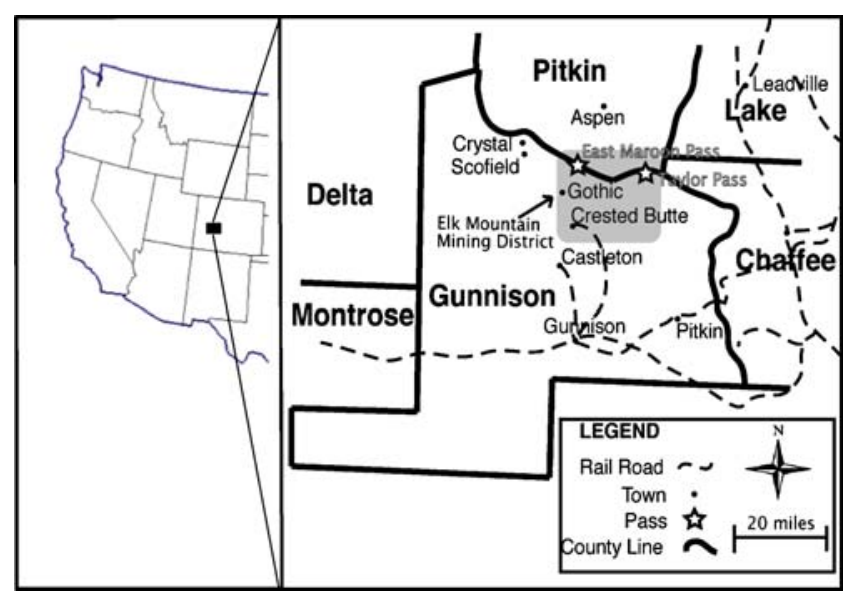

Fig. 1 On the left: map of the western United States. The black rectangle is the general area of Gunnison County, Colorado. On the right: map of Gunnison County, Colorado (circa 1885). The general area from which mines were surveyed for this project is the Elk Mountain Mining District (shaded grey rectangle)

but women were active participants in the boomtown economy, mostly as domestic servants $(70 \%)$ or keeping camp (27\%: United States Bureau of the Census 1880). However, this does not mean they didn't prospect occasionally. In the words of one reporter, "about everybody here prospects or mines, either directly or by proxy" (Strahorn 1881).

Gothic grew fast. W.W. McKee remembers Gothic in 1879 as a bustling town (Wolle 1949). The road to Gothic along the East River was continuously dusty, packed full of freighters, prospectors with bed rolls on their back, and pack trains. The sight and smell of a dead mule was commonplace. The sawmills were kept busy and Gothic quickly sprouted many log cabins, tents, gambling places, and dance halls. Dance hall girls had skirts that rose to the knee, which was shocking for the time. There was a bonfire on Main Street every evening with smoking, socializing, and story telling. There were also occasional footraces or horse races to gamble on, and everyone carried large revolvers. Gothic's economic boom peaked in 1881, supporting over $30-48$ businesses (Colorado State Business Directory 1881; Haase 1971).

The success of a mining camp is determined by being able to sustain that initial economic boom. However, Gothic's economy did not continue to prosper. Edgar Warren (1924) remarks that, "Many of these men who were at Gothic my first year [1882] did not return, or if so, only for a few days. The mines, or prospects-most of them, failed to come up to the expectations of their owners and they abandoned them." The Gothic economy continued to stagnate. By 1885, Lewis Wait, editor of the Gothic Silver Record, complained; "We have lived on Copper Creek soup, Gothic scenery and the promise of business 
subscriptions for three years and we have no idea of being starved out for the next century" (Haase 1971). Indeed, by 1885 the town was all but deserted, supporting only eight registered businesses (Colorado State Business Directory 1885). However, this short burst of mining activity left behind a rich archaeological and written record with which to investigate the economics of silver prospecting.

This paper investigates the potential of the use of public information, as fossilized in local newspapers, to inspire suboptimal CPF strategies among late nineteenthcentury silver prospectors in the Gothic, Colorado area. Successful silver prospectors had to contend with the difficulty of obtaining good information in order to form efficient CPF strategies. Silver ore is extracted from a mine and transported to Gothic for shipping. Individuals must make decisions about the distance away from Gothic to place their mine given transportation costs and the value of ore. Decisions about where to place mines are difficult because silver ore is hidden underground, and even once extracted from bedrock the concentration of silver ore can only be accurately discovered through assaying techniques. Prospectors cannot personally survey and assay every meter of rock in Gunnison County, and may choose to efficiently gather information through social learning.

One of the most reliable social cues would have been public information, produced incidentally by the foraging behaviors of other prospectors. It is likely too high a cost to hike out to a large sample of mining claims to watch others forage for silver. A low cost way to acquire what appears to be reliable public information would be to tap into the rumor mill in the saloon, barbershop, assayers, boarding house, mining journals (Denver Mining Record), or local newspapers. This public information is likely to have shaped their foraging strategies. The information found in the casual rumor mill does not preserve, but fortunately articles in the local newspaper reflect general tenor and ambiance of the town. Boomtown newspapers are an important part of how information is spread among current and potential residents, and probably both started and spread town rumors. The information found in local Gothic newspapers serves as a fossilized record of publicly available information.

Newspapers played an essential role in boomtowns, advertising the town to potential residents and investors and providing an air of permanence to new settlements (Smith 1967). A town would simply not grow without the aid of a newspaper. The Gothic Miner realized the importance of newspapers for boomtowns, "A town without a newspaper in this country, deserves oblivion-and will get it" (October 15th, 1881). Gothic newspapers produced highly convincing evidence of Gothic's value. The
Rocky Mountain News (1879-1885) reports of the success of the everyman, "There can be no doubt as to the quantity and richness of the mineral in this section. Not long ago a young man from Arkansas located in Gothic and in four hours after his arrival made a discovery ... He has named his claim for his sweetheart and proposes to marry and keep house in Gothic" (March 30th, 1880). The Silver Record even calls on advice of experts, "Professor Richardson of Gunnison City, who has been in this country collecting ore for the Denver exposition says that these Elk Mountains contain more mineral and mineral of a higher character than anywhere else in the Gunnison County, or perhaps in the State of Colorado" (July 22nd, 1882).

Newspapers also provided information about various goods and services for sale, notices about new or abandoned mining claims, legal notices concerning action against negligent mining partners, and was often the miner's only way of staying in touch with the world from the distant frontier (Smith 1967; Haase 1971). Only eight of 1,225 Gothic residents stated they could not read (United States Bureau of the Census 1880). Given the importance of the information found in newspapers, even those with limited reading ability probably chatted with readers about the content of newspaper articles. Thus, information found in local newspapers is a good diagnostic of publicly available information.

While newspapers may appear to provide reliable public information about prospecting activities, this may not be true. Boomtown newspapers had large incentives to produce propaganda portraying their town as an exceptionally good investment and a thriving community (Smith 1967). If they could convince potential migrants and investors of these facts, the newspaper and other businesses would thrive. If Gothic mineral prospectors allowed propaganda about the high quality of local silver ore to shape their CPF decisions, they will overestimate the value of a load of silver ore. Overestimating the value of silver could lead prospectors to think they can endure higher transportation costs than are actually profitable. Thus, Gothic prospectors who rely on newspaper information will tend to place their silver mines at a much further distance from Gothic than is actually profitable given the lower concentration of silver in local ore. The goal of this paper is to build a CPF model that predicts the distance from a central shipping location a silver prospector should locate a mine, given the value of local silver ore and the optimistic values of ore published in local newspapers. Through field collections of GPS coordinates for Gothic area mines, actual distances from mines to Gothic can be compared to model estimates. This will allow for a test of the importance of public information in determining mine locating behavior. 


\section{Developing the Central Place Foraging Model}

I assume that prospectors place claims with the design of extracting silver ore and delivering it to a central market (Gothic) to make the greatest possible profit. If these prospectors have good estimates about environmental parameters such as costs of transportation and the value of silver ore, the longest profitable distance at which prospectors will place claims will be where the profits accrued from a load of ore will be equal the costs of prospecting and lost opportunity costs. Shorter distances, of course, produce net gains. A model using these assumptions can be constructed and compared to actual mining behavior from the Gothic area.

This model will predict the one-way distance $\left(d_{o}\right)$ at which the profit from a load of ore equals the costs of ore transportation and lost opportunity costs. In the simplest one-man mining operation, the costs of ore transportation are minimal because a miner simply loads up a backpack full of ore. The largest cost of ore transportation is the lost opportunity for earning money as a wage laborer in town during the time a man takes to hike to the mine and bring back ore. There were other highly lucrative opportunities besides wage labor in a boomtown such as Gothic, like building a small hardware store, owning a saloon, running a boarding house, or becoming a speculator in mining properties (Smith 1967). However, few individuals ${ }^{2}$ in Gothic had the startup capital necessary for these ventures (in 1880 median tax valuation $\$ 60$ : Gunnison County tax records 1880-1881). Therefore the value of a load of ore in dollars $(l)$ :

$l=w d_{r} / s$

where, $w$ is the typical hourly wage (in dollars per hour), $s$ is the walking speed of a man (in kilometers per hour), and $d_{r}$ is the round-trip distance (in kilometers). Solving for the maximum one-way distance $\left(d_{o}\right)$ at which a mining claim would be profitable given transportation costs:

$d_{o}=1 / 2 d_{r}=l s /(2 w)$.

To calculate the value of a load of silver:

$l=v m k$

where, $v$ is the amount the mill will pay per ounce of silver (in dollars), $m$ is the ounces of silver per kilogram of ore,

\footnotetext{
${ }^{2}$ All Gothic prospectors and miners were male (United States Bureau of the Census 1880), and thus without capital had few job opportunities except wage labor and prospecting. This is the focus of this paper. However, women may have had other job opportunities available to them without capital, such as keeping camp and being a laundress.
}

and $k$ is the number of kilograms a man carries in one trip. Substituting:

vmks $/(2 w)=d_{o}$.

Thus, the longest one-way distance $\left(d_{o}\right)$ away from Gothic at which a miner could at least break even is the value a mill will pay per ounce of silver $(v)$ multiplied by the ounces of silver per kilogram of local ore $(\mathrm{m})$, multiplied by the weight of a one-man load $(k)$, multiplied by walking speed $(s)$ divided by two times the typical hourly wage $(w)$.

This model will make the same prediction for a one-man claim as a multi-man claim. If there are multiple men working a claim, the added men could carry extra weight, increasing the load size and increasing the value produced per trip. For instance, a three-man group would multiply the load value by three $(3 v m k)$. However, the lost wages for those men would decrease the value of a load in the same fashion. Lost wages for a three-man load would be $3(w d / s)$. Thus, only the simple one-person model need be considered. While it is possible that at some point mine owners would invest in large machines, this model is designed to test the location and early development of claims only and does not incorporate economies of scale from transport technology. It is likely to be a sufficient model for the Gothic area, as most mines had very minimal excavation and there is little indication of large machines (personal observation).

It is possible that mine owners would try to increase their load size $(k)$ with mule labor. Tax records for the town of Gothic indicate that, contrary to mining town myth, burros were not ubiquitous among prospectors. Few men actually owned animals in Gothic (only 18 mules and asses were registered in Gothic in 1880 for over a thousand inhabitants), but the Colorado business directory and local town newspapers advertised livery stables. Since supply was low and demand high, stables could probably have charged very close to what the market could bear. Thus, the additional value a mule creates will be close to the costs of mule rental. If there were many livery stables in Gothic, it might be possible that competition among stables would encourage stables to lower their prices. However, C.P. Hoyt is the only livery listed in the Colorado State Business Directory for the early days in Gothic (1882, no one is listed for 1880 or 1881). From scanning the advertisements in the Gothic Miner and Elk Mountain Bonanza, C.P. Hoyt started a livery after Burwell and Co. ceased advertising (late 1880). C.P. Hoyt eventually gets competition in the livery business from Melton \& Co. in 1883 (Colorado State Business Directory 1883 and 1884), but the competition does not last and only Hoyt is listed in 1885. It appears the livery business was close to a monopoly in Gothic and companies 
could charge close to the maximum price for a mule that the prospectors would bear. Therefore, the costs and benefits of mule rental will be very close to canceling each other out if they were included in the model. Mule rental prices can safely be excluded from the model as adding mule use and rental into this equation would not create a large effect in the prediction of a one-way distance $\left(d_{o}\right)$.

Preparing this model for empirical testing can be challenging, as constructing well-informed estimates of model parameters requires creative use of fragmentary historical data.

\section{Estimating Hourly Wage (w)}

Local newspapers advertised miner's wages as $\$ 3.50$ a day (Rocky Mountain News March 30th, 1880), and $\$ 3.00$ a day (Rocky Mountain News March 11th, 1881). Skilled laborers like carpenters and bricklayers could make between $\$ 4.50$ and $\$ 6.00$ a day (Rocky Mountain News: August 25th, 1880, March 11th, 1881). Farmhands made as little as $\$ 2$ a day (Rocky Mountain News: August 25th, 1880). Average wages for hard rock mining rarely dropped below $\$ 2.50$ (Wyman 1979). The national average for other types of labor from 1870 to 1899 was around one to two dollars (Wyman 1979).

According to Wyman (1979), the standard 8-h-workday had a history in the West by the 1890 s, but did not become legislated until the twentieth century. Although some miners worked 8-h shifts in the late nineteenth century, many were working much longer hours. Late nineteenthcentury miners would frequently work extremely long hours for daily wage, and a shorter workday was a huge source of contention for early mining unions. Given the likely lack of standardization in wages for remote Gothic, a 10-h-work-day is a reasonable estimate for the average workday.

Unemployment rates are unknown. To compensate for at least some levels of unemployment as well as be most generous to the hypothesis that claims were located for profitable transport to a central place, a minimal value of wage labor will be used $(w=\$ 2.00 / 10 \mathrm{~h}=\$ 0.20 / \mathrm{h})$. This estimate of hourly wage $(w)$ allows a rigorous test of the degree to which prospectors selected suboptimal strategies based on poor information from newspapers.

\section{Estimating Load Size $(k)$}

Physiologists and army researchers have been interested in the physiology of metabolic rate of men carrying backpack loads. Building upon a previous formula by Givoni and Goldman (1971), Pandolf et al. (1977) searched for an equation that would relate body weight, load size, walking speed, slope and terrain type to metabolic rate. This paper spawned subsequent papers searching for maximal and optimal backpack loads. The Pandolf et al. (1977) equation has been empirically tested and found to be accurate for practical purposes across a wide range of loads and gradients (Pimental and Pandolf 1979; Duggan and Haisman 1992). Soule et al. (1978) found that when men (average mass, $72 \mathrm{~kg}$ ) walk on a flat treadmill at $1.8 \mathrm{~m} / \mathrm{s}$ with wellbalanced $60-70 \mathrm{~kg}$ packs they are working at $91-93 \%$ of their maximal oxygen uptake. Most subjects could barely complete the 45 -min walk $(4.8 \mathrm{~km} / \mathrm{h})$ on the treadmill with these loads, and a few became exhausted just prior to the end of the trial. Even with a lighter load of $50 \mathrm{~kg}$ (at $6.4 \mathrm{~km} / \mathrm{h}$ ) not all the subjects could walk the required $20 \mathrm{~min}$. Given the steep, rough terrain of Gothic, this effectively limits load size to around $45 \mathrm{~kg}$. A maximal $45 \mathrm{~kg}$ load may even overestimate what men would willingly carry, since most men would not want to completely exhaust themselves.

Subsequent work attempted to discover the most energetically efficient load size. Pierrynowski et al. (1991) found that this model is very sensitive to how load is determined. Traditionally, models did not give "credit" for a man carrying a certain percentage of his own body weight. If only backpack load was considered, (subjects' average mass $72 \mathrm{~kg}$, walking at $5.54 \mathrm{~km} / \mathrm{h}$ ) the optimal load was $40 \mathrm{~kg}$. When the defined load includes $50 \%$ of the subject's body weight, the optimum decreases to $18 \mathrm{~kg}$. When the defined load includes $100 \%$ of the subject's body weight, the optimum decreases to $7 \mathrm{~kg}$. A later paper (Bastien et al. 2005) expanded that study for slow speeds most appropriate to long walks $(1.3 \mathrm{~m} / \mathrm{s})$ and suggested that a load of one fourth of body mass was optimal. According to this study, a man of $70 \mathrm{~kg}$ should carry a load of $17.5 \mathrm{~kg}$ for a long slow hike. Given the rough terrain, lack of oxygen at high altitudes, credit for carrying body weight, and the small stature of nineteenth-century men, an optimal load estimate of $20 \mathrm{~kg}$ is generous to the hypothesis that claims are located in order to be profitable. Thus, one-way distance $\left(d_{o}\right)$ will be calculated for both optimal $(k=20 \mathrm{~kg})$ and maximal $(k=45 \mathrm{~kg})$ loads.

\section{Estimating Walking Speed $(s)$}

The previous body of literature focused on forcing men to carry particular weights at particular speeds. This is of little use to calculate how fast men would have traveled in the mountainous landscape of the Gothic area. Myles and Saunders (1979) allowed their test subjects to work at their own pace walking on a level road or climbing stairs with load weights $10-40 \%$ of their body weight. Men with $10 \%$ loads choose to walk on a flat road at $6.7 \mathrm{~km} / \mathrm{h}$ and climb stairs at $1.6 \mathrm{~km} / \mathrm{h}$. Men with $40 \%$ loads choose to walk on the flat road at $5.9 \mathrm{~km} / \mathrm{h}$ and climb stairs at $1.3 \mathrm{~km} / \mathrm{h}$. To be 
generous to the hypothesis that claims are located for profitable transport to a central place, a generous value of the speed at which men climb mountains will be used $(s=$ $3 \mathrm{~km} / \mathrm{h}$ ). This estimate of speed ( $s$ ) allows for a rigorous test of the degree to which prospectors were suboptimal foragers.

\section{Estimating the Value of an Ounce of Silver Ore (v)}

The value of an ounce of silver is recorded by the New York stock exchange at $\$ 22.50^{3}$ for 1880 , the peak of the silver boom in Gothic. The Gothic Miner quotes an article from the Denver Inter-Ocean that Colorado produced $\$ 24,000,000$ in mining and reduction but the expenses of labor and infrastructure brought the profit to only $\$ 15,678,400$, which makes the average cost of producing one gold or silver dollar equal to 40 cents (May 28th, 1881). According to these figures, mining in Colorado had a profit margin of 60 cents on every dollar produced. This is a reasonable profit for those who own mines, but this was not the profit margin for miners with unprocessed ore far away from any stock market. It is likely that the prospectors and miners at the very lowest levels of production saw a very thin profit margin or none at all. In fact, the Rocky Mountain News reports that the Griffith mountain debating club decided that the "poorest business known in America was that of prospecting for gold and silver" and that the average wage for prospecting was less than five cents per day and few made even three dollars a day (January 21st, 1881).

The costs of processing and shipping ore were likely to be especially steep for frontier towns like Gothic. Milling records for a local Gothic company in 1883, Central Mining and Milling (1883), indicate that they only gave those with unprocessed ore $\$ 1.1$ dollars an ounce of silver (5\% of the New York exchange rate). While this number seems very small, it is likely to be typical as a somewhat contemporary (1893) Colorado company, the Henriett and Maid Consolidated Mining Co. also typically offered only $5 \%$ of the New York exchange rate (Cavender 1893). So, a good estimate of the value of silver ore for those selling raw ore is $\$ 1.1$ ounce $(v)$.

Estimating the Amount of Silver per Kilogram of Ore $(m)$

The amount of silver in local ore was not easily estimated even for those extracting the ore, and is very tricky to estimate using a fragmentary historical record. However, the Central Mining and Milling Company did leave its 1883 receipt book in Gothic to be collected and archived. This

\footnotetext{
${ }^{3}$ The buying power of one ounce of silver in 1880 has the buying power of \$461.00 current (2008) dollars (Eliasen 2007).
}

book records the assay (number of ounces per ton of ore) for each load brought to the mill. The median, $25 \%$ and $75 \%$ quartiles of this distribution of assays can give an estimate of the number of ounces per ton of rock, which is easily converted to ounces per kilogram (Table 1).

Estimates of the number of ounces per kilogram of rock $(m)$ using 1883 mill records from this area are not necessarily the best estimate given that the mining boom was primarily during 1880 and 1881 . However, it seems unlikely that a very large proportion of the highest quality silver ore was gone in less than two years. Even if the extremely good claims were already tapped out, the median statistic is not highly sensitive to the extremes of the distribution.

It must also be considered that the Central Mining and Milling Company may have cheated miners by recording lower estimates of silver in their books than was actually produced. However, this seems unlikely. The Colorado State Business Directory (1881) lists four assaying companies, who serve as a check for rampant cheating on the part of mill owners. Prospectors would send samples to a local assayer before sending large amounts of ore to the mill and would have some idea of the expected yields. Also, if any prospector had suspicions of being shortchanged, the 1881 Business Directory lists five attorneys. There is also evidence that there were two smelters constructed (Warren 1924; Haase 1971), which would also act as a check against one mill underreporting silver concentrations. A mill that gave poor yields would quickly become avoided in a small town like Gothic if there were other options. Therefore, the estimates based on the Central Mining and Milling Company should provide a good estimate of the ounces of silver per kilogram ore that were actually extracted from the Gothic area.

While it is likely that some prospectors were paying attention to the actual yields from their individual experiences, it is also likely that many prospectors were influenced by publicly available information. The information found in the casual rumor mill does not preserve, but fortunately articles in the local newspaper reflect what information was publicly available. The local newspaper published assays from local Gothic claims. These assays were generally all above $50 \mathrm{oz}$ silver/ton and some as high as 20,000 oz silver/ton (Elk Mountain Bonanza July 1880-March 1881, Gothic Miner April 1881-September 1881, Silver Record June 1882July 1882: $n=128$, median $=221$ oz silver $/$ ton, $25 \%$ quartile $=67 \mathrm{oz}$ silver/ton, $75 \%$ quartile $=640 \mathrm{oz}$ silver $/$ ton). Given the 1883 estimates, these seem to be highly optimistic to utterly fictional. A value of $50 \mathrm{oz}$ of silver per ton is a conservative estimate for the optimistic value of silver perceived by prospectors relying on information from newspapers (Table 1). 
Table 1 The $25 \%$ quartile, median, and $75 \%$ quartiles of the amount of silver per kilogram ore $(m)$ for actual mill runs from the Central Mining and Milling Company ledger, along with an assay value based on information from local Gothic newspapers

\begin{tabular}{|c|c|c|c|}
\hline \multirow[b]{2}{*}{ Source of information } & \multicolumn{3}{|c|}{ Ounces of silver per kilogram ore $\left(\times 10^{-3}\right)$} \\
\hline & $25 \%$ quartile & Median & $75 \%$ quartile \\
\hline Central Mining and Milling Company Mill Ledgers & 5.29 & 14.8 & 28.7 \\
\hline Gothic newspaper (50 oz/ton) & 55.1 & & \\
\hline
\end{tabular}

Putting the Pieces Together

By substitution using parameters estimates from Table 2:

$d_{o}=8.25(20) m=165 m$ OR $\quad d_{o}=8.25(45) m=371.25 m$.

To solve for one-way distance $\left(d_{o}\right)$ given both 20 and $45 \mathrm{~kg}$ loads, substitute in values of the concentration of silver ore in ounces per kilogram $(m)$ from Table 1 . The resulting one-way distances for median and $75 \%$ quartile estimates based on realistic estimates of the concentration of silver $(\mathrm{m})$ for both 20 and $45 \mathrm{~kg}$ loads are calculated. In addition, the one-way distances for a conservative estimate of silver ore concentration based on published in newspaper assays $(m=50 \mathrm{oz}$ silver/ton or $0.05511 \mathrm{oz} / \mathrm{kg}$ ) for both 20 and $45 \mathrm{~kg}$ loads are also calculated.

\section{Collecting Behavioral Data}

The USGS Geologic and Topographical Maps for the OhBe-Joyful (Gaskill et al. 1967, USGS 1961), Gothic (Gaskill et al. 1991, USGS 1961), Maroon Bells (Bryant 1969, USGS 1960), and Snowmass Mountain (Mutschler 1970, USGS 1960) quadrangles as well as local oral history were used to identify regions most likely to contain silver. Several mines and prospects were marked on maps and locals who had hiked the area were frequently able to add more locations of mining activity. Based on this preliminary data, nine mining regions were selected for field surveying

Table 2 This table summarizes the central place foraging model parameter estimates

\begin{tabular}{ll}
\hline Parameter & Estimate \\
\hline$v$ & $\$ 1.1 / \mathrm{oz}$ \\
$m$ & Values from Table 1 (in ounces per kilogram) \\
$k$ & 20 or $45 \mathrm{~kg}$ \\
$s$ & $3 \mathrm{~km} / \mathrm{h}$ \\
$w$ & $\$ 0.20 / \mathrm{h}$ \\
\hline
\end{tabular}

(Fig. 2), at a variety of distances away from the central shipping town of Gothic.

I surveyed these regions for evidence of mining activity using transects that closely followed exposed geological layers most likely to have silver ore (in sedimentary rock surrounding igneous plutons: Guilbert and Park 1986). The sparse subalpine vegetation cover usually allowed for good visibility (on average $40 \mathrm{~m}$ on either side of the transect), but thick aspen or willow groves would sometimes severely limit visibility (down to $5 \mathrm{~m}$ on either side of the transect). I attempted to completely survey the nine selected basins for evidence of mining activity, but it is likely that some mines were missed due to rough terrain and size of the selected basins. Since mines went unfound because of difficult terrain and visibility that was found fairly equally at all distances from Gothic, lost mines were not likely to be systematically biased by distance away from Gothic.

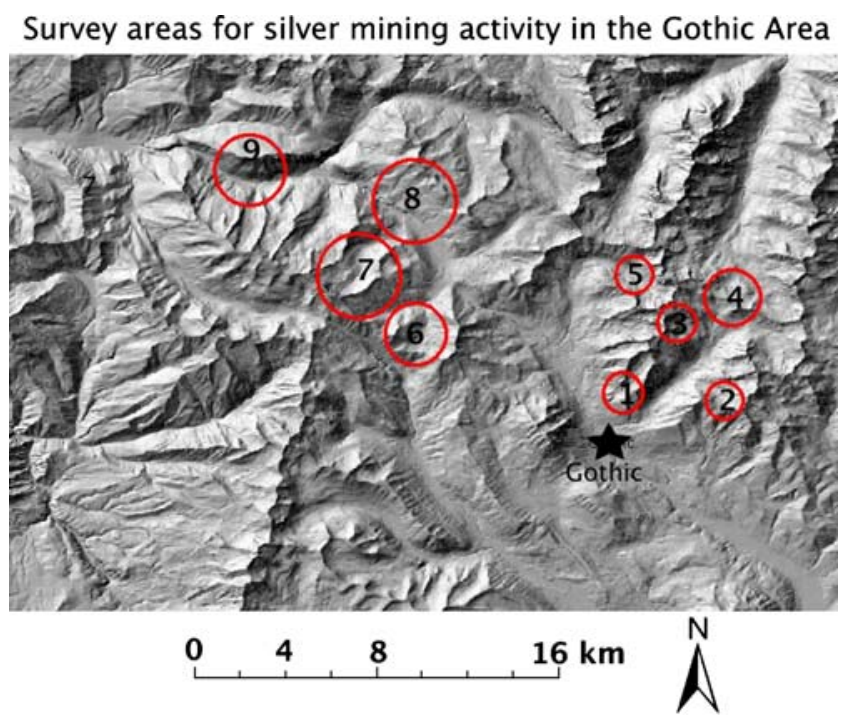

Fig. 2 Map of the surveyed areas of mining activity in the Gothic area. Numbered labels refer to a local land feature near the area. 1 Virginia Basin, 2 Queen's Basin, 3 Sylvanite, 4 East Maroon Pass and Copper Lake, 5 Rustler's Gulch, 6 Paradise Basin, 7 Galena and Treasury Mountains, 8 Schofield Park, 9 Sheep Mountain and the Town of Crystal 
Evidence of mining was easily determined by the presence of excavations (often with straight sides and not easily confused with natural geologic formations), mine tailings, and human debris (cans, nails, metal, etc.). Many mining sites were small ( $44 \%$, up to $5 \mathrm{~m}$ deep) to medium ( $28 \%$, up to $15 \mathrm{~m}$ deep) test pits carved either horizontally (adits) or vertically (shaft) into rock. Only $27 \%$ of the features were considered to be proper mines $(>15 \mathrm{~m}$ deep with large tailings piles, of both shaft and adit types) that would have been excavated over a long period of time. There were small, medium, and large mines spread throughout the surveyed basins. All mining sites (small, medium, proper mine) demonstrate mining interest by prospectors and the investment in at least one load of ore transport. Thus, a least cost path is calculated for each mining site regardless of size. A good number of cabin sites (12) were also identified spread through all basins, which indicates that men saw this region as a long-term investment.

It would be ideal to have a temporal component to the distribution of mines. If transportation is costly, then earlier mines and prospects should be closer to Gothic. Unfortunately, these data are not easily obtained for Gothic. Historical records and mining sites were impossible for me to match with confidence. Historical records often reference natural features no longer present (trees, large boulders) and use archaic measurements. Also, mining claims often switched names or different mining claims would share the same name (e.g., "Buckeye"). Also, diagnostic artifacts (tin cans, nails, buttons) do not have enough resolution to try to put dates on features given the short time period of occupation in Gothic (Hunt 1959; Busch 1981; Sagstetter and Sagstetter 1998). However, I did determine many of the basins had an occupation in the late nineteenth century, indicated by square handmade nails and early hand-soldered tin cans.

The model developed in this paper focuses on initial investment in a mining prospect. It may be productive for future research to focus on later development of this region including cabin sites and serious mine excavation and investment. Well-preserved material remains like those found in the Gothic area have great potential for better understanding life and economic development in boomtowns (Sagstetter and Sagstetter 1998).

At each mining site spatial coordinates (longitude, latitude, and altitude) were recorded using a GPS (Garmin etrex vista). The Minnesota Department of Natural Resources (2004) Garmin Application (v. 5.1.1) was used to transfer the GPS waypoints into a shapefile (.shp) to create an arcGIS (v 9.1) map.

The Environmental Systems Research Institute (2007) arcGIS (v9.1) spatial analyst program was used to identify the paths an individual would walk, given the supposition that they were opposed to walking on steep slopes ${ }^{4}$ (see Table 3 for cost assignments). ${ }^{5}$ Note that when these paths were layered on top of the USGS topographic maps, these paths tended to follow to modern hiking trails and jeep roads. ${ }^{6}$ In short, where I could make a comparison, the software and my parameter choices did a good job of emulating the kind of routes selected by nineteenthcentury prospectors. The distance of these least cost paths is the actual one-way distance $\left(d_{o}\right)$ that silver prospectors located their claims away from Gothic, and can be compared to the predictions $\left(d_{o}\right)$ from the CPF models.

\section{Gothic Prospectors Choose Inefficient Foraging Strategies}

Figure 3 compares the lengths (in kilometers) of the least cost paths from each mining area to Gothic to an array of model predictions of the longest profitable oneway distances based on 20 or $45 \mathrm{~kg}$ load sizes $(k)$, reasonable estimates of the concentration of silver per kilogram ore $(m)$, and estimates based on the over

\footnotetext{
${ }^{4}$ Wood and Wood (2006) argue that arcGIS calculations of slope based on the greatest difference in elevation between one cell and any of the surrounding eight cells is a highly problematic way to calculate forager movement. This maximum value approach eliminates the benefit a forager would get from downhill travel, and is not tied to the actual energetic costs for foragers on various slopes. They propose a more human-centered metric focusing on energetic costs, and demonstrate the utility of this approach to predict travel paths through the Sierra Nevada mountain range. These concerns are valid for those wishing to predict the actual path of forager movement over a complex landscape. However, the scientific questions for this paper concern distance from Gothic. While a simple straight line distance from mining claim to Gothic certainly misrepresents the actual distance a forager would walk, I believe that using the slope function in arcGIS to calculate least cost paths is a reasonable approximation for this project. It is not likely that the distance of the least cost paths created by arcGIS will be substantially different than those based on an energetic model like that of Wood and Wood (2006).

${ }^{5}$ A digital elevation model (DEM) (2005) was acquired from the USGS with elevation measured every one third arc sec or approximately every $10 \mathrm{~m}$. The slope tool from the Spatial Analyst extension package was used to calculate the steepest incline defined by each one third arc second cell and its eight neighbors (measured in degrees). These calculations were then recoded so that bigger slopes received higher numbers, or costs, and smaller slopes received lower costs (see Table 3 for details). The Cost Weighted Distance tool of the Spatial Analyst package was used to create a Cost-Distance and CostDirection raster for each one third arc second $(10 \mathrm{~m})$ cell towards the location of the town of Gothic. These calculations are used by the Shortest Path tool, which can be used to find the shortest path from each point of mining activity to Gothic. The Measure tool was used to find the distance of each one of these paths (in kilometers).

${ }^{6}$ Note that trails and jeep roads are narrow and follow natural contours. The roads themselves should not make a large impact on the slope landscape enough to drive the positioning of least-cost paths.
} 
Table 3 Slopes reclassified into costs for arcGIS spatial analyst tool

\begin{tabular}{lc}
\hline Slope (in degrees) & Cost $(1-10)$ \\
\hline $0-8$ & 1 \\
$8-16$ & 1 \\
$16-24$ & 2 \\
$24-32$ & 3 \\
$32-40$ & 4 \\
$40-48$ & 7 \\
$48-56$ & 8 \\
$56-64$ & 9 \\
$64-72$ & 10 \\
$72-80$ & 10 \\
\hline
\end{tabular}

Costs were assigned so that a forager would be less inclined to walk on the steepest slopes and most inclined to walk on a slope of less than $16^{\circ}$

enthusiastic assays $(m)$ published in the newspaper. Models were designed to be generous towards the hypothesis that prospectors made claims that could be profitably worked to extract silver ore and transport it to Gothic for sale. If mining activity is located at a distance greater than predicted by the model based on actual amounts of silver in local ore, and is instead located at a distance that would be predicted by a model based on newspaper estimates, then prospectors rely heavily on public information of poor quality.

The one-way distances estimated by the economic model for both 20 and $45 \mathrm{~kg}$ loads using the median and $75 \%$ quartile of the distribution of assay values from 1883 Central Mining and Milling Company records were shorter than a large portion of the actual least cost path distances from mining activity to Gothic (light shaded bar $-k=20$, median assay $d_{o}=2.442,75 \%$ quartile assay $d_{o}=4.736$; dark shaded bar $-k=45$, median assay $d_{o}=5.495,75 \%$ quartile assay $d_{o}=10.655$; Fig. 3 ). In order to enclose most of the mines within the marginally profitable distance from Gothic (according to the model), a man must carry a $45 \mathrm{~kg}$ load and the ore must be in a concentration of $50 \mathrm{oz}$ silver/ton (similar to advertised estimates in the local newspapers) (bold grey line $d_{o}=$ 20.456; Fig. 3). Even carrying a $20 \mathrm{~kg}$ load and having an optimistic estimate of silver ore concentration $(50 \mathrm{oz} /$ ton, similar to advertised estimates in the newspapers) does not account for the placement of a large clump of mines (dotted bold grey line $d_{o}=9.09$; Fig. 3 ). These data support the hypothesis that prospectors relied heavily on the exaggerated ore concentrations found in the local rumor mill (as indicated by the newspaper), and chose to locate their claims at a much greater distance than was in reality profitable.

\section{Discussion}

The process that leads to "irrational exuberance" among investors during mass economic events like Dutch tulip mania, the dot.com boom, or mining boomtowns is not well understood, but media do appear to play an important role (Shiller 2000). It is a puzzle why individuals would allow questionable information from the media to dictate their economic strategies. However, this behavior makes sense from an evolutionary perspective. When individuals choose strategies under conditions of limited time and information, they may make efficient short cuts by being social learners (Boyd and Richerson 1985; Richerson and Boyd 2005). Public information is a particularly reliable social cue since it is produced incidentally by the foraging behavior of others, and thus is not particularly susceptible to purposeful deception (Valone and Templeton 2002). There should be strong selective pressures for cognitive mechanisms that rely on public information. Media can exploit these cognitive mechanisms. When reporting about the foraging events of others, media produce what appears to be public information but may instead be biased to further their own interests. Those individuals who rely on media for social

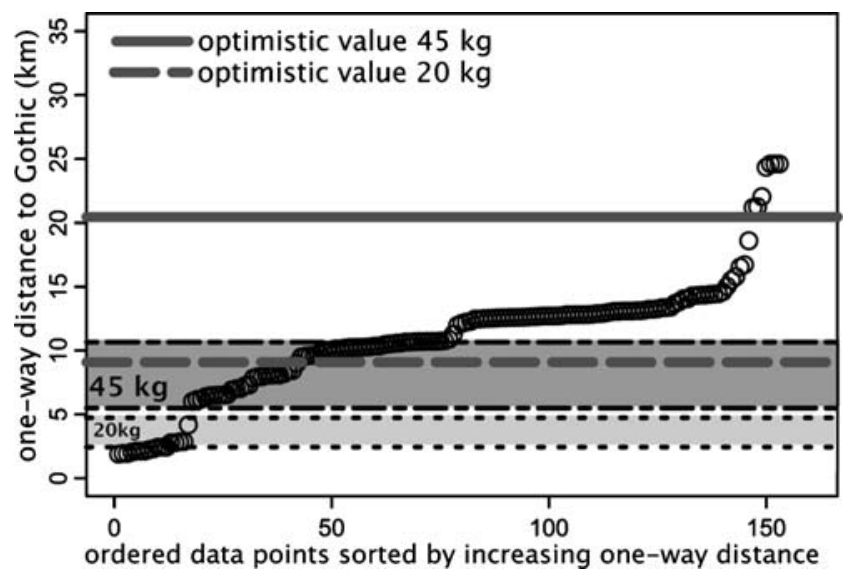

Fig. 3 Graph of the distance to travel on the least costly path from each point of mining activity to the town of Gothic. Measurements of the length of the least cost path from each area of mining activity to Gothic (in kilometers) were sorted by length. These lengths were plotted against an index of their spreadsheet row number (open circles). Model estimates of the longest profitable one-way distance (in kilometers) based on the median and $75 \%$ quartile values of mill runs from the Central Mining and Milling Company ledger and a $40 \mathrm{~kg}$ load were plotted as horizontal dotted lines. Model estimates of the longest profitable one-way distance (in kilometers) based on the median and $75 \%$ quartile values of mill runs from the Central Mining and Milling Company ledger and a $70 \mathrm{~kg}$ load were plotted as a dashdotted lines. Model estimates of the longest profitable one-way distance (in kilometers) based on newspaper assays for 40 and $70 \mathrm{~kg}$ loads are plotted as horizontal bold grey lines. Note that the models that best explain the actual distance of mines from Gothic (open circles) are the models based on the over enthusiastic assays from newspapers 
cues are mislead. Even if only a few individuals in a population use this faulty information to choose strategies, it can spur large groups of social learners to choose poor strategies through informational cascades (Bikhchandani et al. 1992; Morris and Shin 2002). These cognitive processes may be the underlying mechanisms behind mass economic hysteria or irrational exuberance.

Here, we investigate the role of the media and public information in shaping economic strategies by comparing actual and optimal central place foraging (CPF) behaviors of silver prospectors in Gothic, Colorado. If individuals use individual learning, they should be obtaining a small but accurate sample of the amount of silver in local ore $(m)$ and select optimal strategies However, CPF models based on the actual amounts of silver in local ore from ore processing records predict that mines should be located within a much smaller radius from Gothic than silver prospectors actually located mines (Fig. 3). These data indicate that it is not likely that prospectors located mines based on individually learned estimates of environmental parameters. The CPF model based on information about the value of local silver ore from local newspapers better predicts the actual distances at which silver prospectors located claims (Fig. 3). Information contained in local newspapers is a fossilized version of what information would have been publicly available at the time in other more informal sources (e.g., saloon). These data support the hypothesis that prospectors in uncertain circumstances relied on public information, which leads to sub-optimal foraging strategies involving placing mines much farther from Gothic than was profitable for extracting silver ore.

Historical estimates of model parameters were scant due to the poor record keeping and preservation endemic in frontier regions. However, model parameters were always designed to be generous towards the hypothesis that prospectors made claims that could be profitably worked to extract silver ore and transport it to Gothic. For instance, actual levels of unemployment were unknown and so wage labor $(w)$ estimates were based on a very low estimate in order to account for some level of unemployment. This allows for a conservative test of the hypothesis that prospectors were suboptimal foragers.

It would have been more satisfying to perform a sensitivity analysis, assigning parameters with some sort of density distribution to gauge how model estimates vary with small fluctuations in parameter estimates. Unfortunately, this is not practical with this data set. In particular, it would be intriguing to allow wage labor rates to fluctuate. Since there is no record of unemployment or exact wages per hour over any period of time, it would be difficult to set up a density distribution of wages in an informed way. More complicated models with more complete data could attempt to substitute parameters with functions rather than point estimates.

Mass hysteria and over-enthusiastic optimism over a new mining district was common in Western boomtowns. Optimism about finding the next big strike often substituted for realistic economics (Smith 1967). Few participants were not caught up in the excitement. Public information gleaned from both informal and written sources, like the newspaper, led entrepreneurs astray. Indeed, Edgar Warren (1924), an assayer in Gothic, had "no hesitation" in going into business in Gothic due to the "glowing accounts" coming from the Elk Mountain region. However, he also spent most of his time playing cards and hiking in the mountains since reality was not so "glowing". The media spoke of promise and prosperity and not caution. This hype led to the quick boom of Gothic, but the lack of good prospects led to the equally quick bust.

The fact that individuals extracting frontier resources tended to rely heavily on information from local newspapers should be of interest for those attempting to understand the boom-bust cycle of frontier towns, and the impact human resource extraction has on local ecosystems. Models based on perfect information and rational behavior will tend to underestimate the scope of the impact humans have on the environment. For example, petitions for increased governmental investment in infrastructure in developing regions might initially seem to be well founded given the number of people and towns in an area. However, population may be temporarily elevated by the influx of irrationally exuberant investors. For example, labor and capital were invested in Gothic toll roads (Gothic Miner April 30th, 1881, August 13th, 1881, September 17th, 1881, October 10th, 1881 and Silver Record June 24th, 1882), many of which are still in reasonably good order today, but the town of Gothic was quickly abandoned. These results should be of interest to landscape archaeologists, as traditional CPF models may tend to underestimate the distance away from a central town that we would expect to find resource extraction sites.

This pattern of exploitation beyond a profitable point may be exacerbated in non-diversified economies with few opportunity costs. According to the CPF model, if opportunity costs are low or zero, there is little incentive to not prospect every available spot. So, in economies such as Gothic where there are low opportunity costs, we would expect high degrees of overexploitation and sprawl in resource extraction sites. An effective part of a resource management plan may be to provide outside opportunities to resource extraction to avoid every small pool of resources from being exploited.

The sprawl of exploitation may also be exacerbated in ephemeral economies. The mining boom in Gothic lasted less than five years. It is likely that in novel environments 
individuals cannot rely on their own reliable information and may instead rely heavily on social learning and public information. It is likely that if mining in Gothic was sustained for a longer period of time, like 10 years, prospectors would have become wary of the media as a source of information, as their own experiences led to corrected estimates for the value of silver in Gothic. Perhaps the media may have even become a less blatant source of mis-information. If novel and ephemeral economies are more susceptible to this bias, resource management plans may have particular problems with new extraction sites with neophyte extractors. Effective management plans should focus on good education and perhaps provide fact checks of media to provide foragers with reasonable information and help counteract the problems of overenthusiastic foraging.

Acknowledgments Many thanks to Bruce Winterhalder, Monique Borgerhoff Mulder, Mark Grote, Richard McElreath, and two anonymous reviewers for the time they devoted to improving this project. Thanks also to my tireless research assistants, Mary King, Devin Snyder, Jessica Rockwell, Emily Bergmann and Colin Cannell for bravely spelunking in mines and pouring over piles of dusty archives. This project was made possible through logistical support by the Rocky Mountain Biological Laboratory and funding from several UC Davis Anthropology Department block grants and a Grant in Aid of Research from Sigma Xi.

Open Access This article is distributed under the terms of the Creative Commons Attribution Noncommercial License which permits any noncommercial use, distribution, and reproduction in any medium, provided the original author(s) and source are credited.

\section{References}

Bastien, G. J., Willems, P. A., Schepens, B., and Heglund, N. C. (2005). Effect of Load and Speed on the Energetic Cost of Human Walking. European Journal of Applied Physiology 94: 76-83.

Beck, C., Taylor, A. K., Jones, G. T., Fadem, C. M., Cook, C. R., and Millward, S. A. (2002). Rocks are Heavy: Transport Costs and Paleoarchaic Quarry Behavior in the Great Basin. Journal of Anthropological Archaeology 21: 481-507.

Bettinger, R. L., and Malhi, R. (1997). Central Place Models of Acorn and Mussel Processing. Journal of Archaeological Science 24: 887-899.

Bikhchandani, S., Hirshleifer, D., and Welch, I. (1992). A Theory of Fads, Fashion, Custom, and Cultural Change as Informational Cascades. The Journal of Political Economy 100: 5992-1026.

Billington, R. A. (1967). The American Frontier. In Bohannan, P., and Plog, F. (eds.), Beyond the Frontier: Social Process and Cultural Change, The Natural History Press, Garden City, pp. 3-24.

Boyd, R., and Richerson, P. (1985). Culture and the Evolutionary Process. University of Chicago Press, Chicago.

Bryant, B. (1969). Geologic Map of the Maroon Bells Quadrangle, Pitkin and Gunnison Counties, Colorado: U.S. Geological Survey Geologic Quadrangle Map GQ-788, scale 1:24,000.

Busch, J. (1981). An Introduction to the Tin Can. Historical Archaeology 15: 95-103.
Cannon, M. D. (2003). A Model of Central Place Forager Prey Choice and an Application to Faunal Remains from the Mimbres Valley, New Mexico. Journal of Anthropological Archaeology 22: 1-25.

Cavender, C. (1893). Ore ledger for Henriett and Maid Consolidated Mining Company. Colorado Historical Society, Denver.

Central Mining and Milling Company (1883). Ore Ledger. Rocky Mountain Biological Laboratory Archives, Gothic.

Colorado State Business Directory (1880). J.A. Blake, Denver.

Colorado State Business Directory (1881). Jackson, Denver.

Colorado State Business Directory (1882). J.A. Blake, Denver.

Colorado State Business Directory (1883). J.R. Ives and Co., Denver.

Colorado State Business Directory (1884). J.R. Ives and Co., Denver.

Colorado State Business Directory (1885). J.R. Ives and Co., Denver.

Cont, R., and Bouchaud, J.-P. (2000). Herd Behaviors and Aggregate Fluctuations in Financial Markets. Macroeconomic Dynamics 4: 170-196.

Dall, S. R. X., Giraldeau, L.-A., Olsson, O., McNamara, J. M., and Stephens, D. W. (2005). Information and its Use by Animals in Evolutionary Ecology. Trends in Ecology and Evolution 20: 4187-193.

Danchin, E., Giraldeau, L.-A., Valone, T. J., and Wagner, R. H. (2004). Public Information: From Nosy Neighbors to Cultural Evolution. Science 305: 487-491.

Digital Elevation Model (one third arc sec) for Gothic, Snowmass, Oh-Be Joyful, and Maroon Bells Quadrangles. Department of the Interior. United States Geological Survey. Washington, D.C. Retrieved from Geo Community http://data.geocomm.com/dem/ April 2005.

Dornhaus, A., Collins, E. J., Dechaume-Moncharmont, F.-S., Houston, A. I., Franks, N. R., and McNamara, J. M. (2006). Paying for Information: Partial Loads in Central Place Foragers. Behavioral Ecology and Sociobiology 61: 151-161.

Duggan, A., and Haisman, M. F. (1992). Prediction of the Metabolic Cost of Walking With and Without Loads. Ergonomics 35: 4417426.

Eliasen, A. (2007). Historical Currency Conversions. Retrieved April 5th, 2008 from http://futureboy.home.ip.net/fsp/dollar.fsp.

Elk Mountain Bonanza (July 1880-March 1881). Various articles. Accessed at the Leslie J. Savage Library, Western College, Gunnison.

Environmental Systems Research Institute (2007). arcGIS v 9.1 with Spatial Analyst.

Gaskill, D. L., Godwin, L. H., and Mutschler, F. E. (1967). Geologic Map of the Oh-Be-Joyful Quadrangle, Gunnison County, Colorado: U.S. Geological Survey Geologic Quadrangle Map GQ-578, scale 1:24,000.

Gaskill, D. L., Mutschler, F. E., Kramer, J. H., Thomas, J. A., and Zahony, G. (1991). Geologic Map of the Gothic Quadrangle, Gunnison County, Colorado: U.S. Geological Survey Geologic Quadrangle Map GQ-1689, scale 1:24,000.

Gigerenzer, G., and Todd, P. M. (1999). Fast and frugal heuristics. In Gigerenzer, G., and Todd, P. M. (eds.), Simple Heuristics That Make Us Smart, Oxford University Press, Oxford.

Giraldeau, L.-A., Valone, T. J., and Templeton, J. J. (2002). Potential Disadvantages of Using Socially Acquired Information. Philosophical Transactions of the Royal Society of London, B 357: $1559-1556$.

Givoni, B., and Goldman, R. F. (1971). Predicting Metabolic Energy Cost. Journal of Applied Physiology 30: 3429-433.

Gothic, CO Topographic Map. 1:24,000. 1961. Department of the Interior. United States Geological Survey. Washington, D.C. Retrieved from USGS http://topomaps.usgs.gov/drg/ April 2005.

Gothic Miner (April 1881-September 1881). Various articles. Accessed at the Leslie J. Savage Library, Western College, Gunnison. 
Guilbert, J. M., and Park, C. F. (1986). The Geology of Ore Deposits. W.H. Freeman and Company, New York.

Gunnison County Recorder's Office (1879). County Records. Book 2. Gunnison, Colorado

Gunnison County Recorder's Office. (1880-1881). Gunnison County Tax Records. Gunnison, Colorado

Haase, C. L. (1971). Gothic, CO City of Silver Wires. Western College. Master's Dissertation, Western State College, Gunnison.

Hunt, C. B. (1959). Dating of Mining Camps with Tin Cans and Bottles. Geotimes 15: 8-1034.

Krebs, J. R., and Davies, N. D. (1997). The evolution of behavioral ecology. In Krebs, J. R., and Davies, N. D. (eds.), Behavioral Ecology: An Evolutionary Approach. Blackwell Science, Oxford, pp. 1-12.

Laland, K. N. (1996). "Is Social Learning Always Locally Adaptive?" Animal Behaviour 52: 637-640.

Laland, K. N., and Brown, G. R. (2002). Sense and Nonsense: Evolutionary Perspectives on Human Behavior. Oxford University Press, Oxford.

Landa, J. T., and Wang, X. T. (2001). Bounded Rationality of Economic Man: Decision Making Under Ecological, Social, and Institutional Constraints. Journal of Bioeconomics 3: 217-235.

Maroon Bells, CO Topographic Map. 1:24,000. 1960 Photo revised 1987. Department of the Interior. United States Geological Survey. Washington, D.C. Retrieved from USGS http://topomaps.usgs.gov/ drg/ April 2005.

Metcalfe, D., and K. R. Barlow (1992). A Model of Exploring the Optimal Trade-Off Between Field Processing and Transport. American Anthropologist 94: 340-356.

Minnesota Department of Natural Resources. DNRGarmin GPS Application version 5.1.1. Retrieved May 10th, 2004.

Morris, S., and Shin, S. H. (2002). Social Value of Public Information. The American Economic Review 92: 51521-1534.

Mutschler, F. E. (1970). Geologic Map of the Snowmass Mountain Quadrangle, Pitkin and Gunnison Counties, Colorado: U.S. Geological Survey Geologic Quadrangle Map GQ-853, scale $1: 24,000$.

Myles, W. S., and Saunders, P. L. (1979). The Physiological Cost of Carrying Light and Heavy Loads. European Journal of Applied Physiology 42: 125-131.

Oh-Be-Joyful, CO Topographic Map. 1:24,000. 1961. Photo inspected 1973. Department of the Interior. United States Geological Survey. Washington, D.C. Retrieved from USGS http://topomaps.usgs.gov/ drg/ April 2005.

Orians, G. H., and Pearson, N. E. (1979). On the theory of central place foraging. Analysis of Ecological Systems. D. J. e. a. Horn. Columbus, Ohio, Ohio State University Press:155-177.

Pandolf, K. B., Givoni, B., and Goldman, R. F. (1977). Predicting Energy Expenditure with Loads While Standing or Walking Very Slowly. Journal of Applied Physiology 43: 4577-581.

Pierrynowski, M. R., Winter, D. A., and Norman, R. W. (1991). Metabolic Measures to Ascertain the Optimal Load to be Carried by Man. Ergonomics 24: 5393-399.

Pimental, N. A., and Pandolf, K. B. (1979). Energy Expenditure While Standing or Walking Slowly Uphill or Downhill with Loads. Ergonomics 22: 8963-973.

Prins, H. H. T. (1996). Ecology and Behavior of the African Buffalo. Chapman and Hall, London.
Richerson, P., and Boyd, R. (2005). Not by Genes Alone: How Culture Transformed Human Evolution. University of Chicago Press, Chicago.

Rocky Mountain News (1879-1885). Various articles. Accessed at the Denver Public Library, Denver.

Sagstetter, B., and Sagstetter, B. (1998). The Mining Camps Speak: A New Way to Explore the Ghost Towns of the American West. BenchMark, Denver.

Shiller, R. J. (2000). Irrational Exuberance. Princeton University Press, Princeton.

Wolle, M. S. (1949). Stampede to Timberline: The Ghost Towns and Mining Camps of Colorado. M.S. Wolle, Boulder.

Silver Record (June 1882-July 1882). Various articles. Accessed at the Leslie J. Savage Library, Western College, Gunnison.

Smith, D. A. (1967). Rocky Mountain Mining Camps, Indiana. Indiana University Press, Bloomington.

Smith, E. A., and Winterhalder, B. (1992). Natural selection and decisions making: Some fundamental principles. In Smith, E. A., and Winterhalder, B. (eds.), Evolutionary Ecology and Human Behavior. Aldine de Gruyter, New York, pp. 25-60.

Smuts, B. B., Cheney, D. L., Seyfarth, R. M., and Wrangham, R. W. (1987). Primate Societies. University of Chicago Press, Chicago.

Snowmass Mountain, CO Topographic Map. 1:24,000. 1960 Photo revised 1987. Department of the Interior. United States Geological Survey. Washington, D.C. Retrieved from USGS http:// topomaps.usgs.gov/drg/ April 2005.

Soule, R. G., Pandolf, K. B., and Goldman, R. F. (1978). Energy Expenditure of Heavy Load Carriage. Ergonomics 21: 373-381.

Strahorn, R. E. (1881). Gunnison and San Juan. A late and reliable description of the wonderful gold and silver belts and iron and coal fields of that newest and best land for prospector and capitalist, southwestern Colorado ... as presented in a series of letters written to the "New York world" by its special correspondent, "R. E.S." Also, containing a valuable appendix on mining laws. The New West, Omaha.

United States Bureau of the Census. 1880. Federal Population Census. Washington

Valone, T. J., and Templeton, J. J. (2002). Public Information for the Assessment of Quality: A Widespread Social Phenomenon. Philosophical Transactions of the Royal Society of London, B. 357: 1549-1557.

Vandenbusche, D. (1980). The Gunnison Country. B\&B, Gunnison.

Warren, E. (1924). Diary of Edgar Warren, Written in 1924 Recalling the Old Days, May 1882-Fall 1896. Rocky Mountain Biological Laboratory Archives, Gothic.

Wermer, R. (1999). "Mutual Fund Herding and the Impact on Stock Prices." The Journal of Finance 54(2): 581-622.

Winterhalder, B., and Smith, E. A. (1992). Evolutionary ecology and the social sciences. In Winterhalder, B., and Smith, E. A. (eds.), Evolutionary Ecology and Human Behavior. Aldine de Gruyter, New York, pp. 3-24.

Wood, B., and Wood, Z. (2006). Energetically optimal travel across terrain: visualizations and a new metric of geographic distance with archaeological applications. Proceedings of SPIE Electronic Imaging, San Jose, January 2006

Wyman, M. (1979). Hard Rock Epic: Western Miners and the Industrial Revolution. University of California Press, Berkeley. 